\title{
A Systematic Revision of the Genus Plectranthus L. (Lamiaceae) in Saudi Arabia Based on Morphological, Palynological, and Micromorphological Characters of Trichomes
}

\author{
Kadry N. Abdel Khalik ${ }^{1,2}$ \\ ${ }^{1}$ Department of Biology, Faculty of Applied Science, Umm Al-Qura University, Makkah, Saudi Arabia \\ ${ }^{2}$ Botany Department, Faculty of Science, Sohag University, Sohag, Egypt \\ Email: kadry3000@yahoo.com
}

Received 11 May 2016; accepted 19 July 2016; published 22 July 2016

Copyright (C) 2016 by author and Scientific Research Publishing Inc.

This work is licensed under the Creative Commons Attribution International License (CC BY). http://creativecommons.org/licenses/by/4.0/

c) (†) Open Access

\section{Abstract}

This study aims to investigate the morphology and ultrastructure characters of pollen grains and trichomes in order to evaluate their systematic value of these characters in specific and intraspecific separation of the Saudi Arabian Plectranthus species. A critical systematic revision of 7 species of Plectranthus (Lamiaceae) in Saudi Arabia was conducted by means of numerical analyses based on thirty-one morphological characters, including vegetative parts, seeds, pollen grains, and trichomes. Macro- and micro-morphological characters, including seed and pollen shape, size, coat sculpture, trichome structure, were studied. It reveals the presence of seven species, including two endemic species. The pollen grains were zonocolpate, hexacolpate, prolate to subprolate. Three types of exine ornamentation were recognized. Also, two trichome types could be distinguished and classified into glandular and non-glandular. The glandular trichomes could be distinguished as peltate, capitate and digitiform. The eglandular trichomes were single, uniseriate, multicellular. Pollen and trichome characters were found to be valuable, while seed characters presented only minor taxonomic value. On the basis of UPGMA clustering analysis four branches and clusters were distinguished. The results offer useful data for evaluating the taxonomy of Plectranthus both at subgeneric and sectional levels. Our results indicated some degree of similarity among the species of subgenus Burnatastrum. Plectranthus arabicus is considered as a separate group and may be treated as separate subgenus. Furthermore, the endemic species Plectranthus asirensis and 
Plectranthus hijazensis constitute a monophyletic group and there are close relationships between this group and Plectranthus tenuiflorus. A key for the identification of the investigated taxa based on studied characters is provided.

\title{
Keywords
}

\author{
Morphological, Palynology, Seed, Taxonomic Revision, Trichomes
}

\section{Introduction}

Lamiaceae is a large family that is widely spread and in nearly all habitats and altitudes its species can be found. The genus Plectranthus L'Hér. is one of the largest genera of Lamiaceae, belonging to the subfamily Nepetoideae, tribe Ocimeae, subtribe Plectranthinae. It comprises about 300 species distributed in both tropical and warm regions of the Old World [1] [2]. A phylogenetic study of the tribe Ocimeae, based on plastid genes to which Plectranthus belongs, showed that Plectranthus was paraphyletic [3]. [4] [5] monographed the species of Plectranthus, and divided Plectranthus into seven sections: Germanea (Lam.) Benth., Coleoides Benth., Heterocylix Benth., Melissoides Benth., Isodon Schrad. ex Benth., Pyramidium Benth., and Amethvstoides Benth. However, in [6], Bentham latter revised this arrangement, recognizing two primary groups: Sect. Germanea and sect. Isodon. In sect. Germanea, with Germanea and Coleoides as subsections (in which the great majority of conventional Plectranthus spp. are placed), the calyx is 2-lipped with the upper lip consisting of a single broad tooth and the lower lip of four narrower acute or acuminate teeth: the cymes are usually sessile with the pedicels arising from the axis of the inflorescence. Sect. Isodon, with Isodon, Pyramidium, Amethvstoides and Melissoides as subsections, was distinguished by the calyx being equally 5-toothed, in some groups more or less 2-lipped with the upper lip composed of 3 teeth and the lower lip of 2 teeth: the cymes are pedunculate and branched. A similar classification was accepted by [7], however, Germanea and Isodon were treated as subgenera. In each subgenus the largest sections, Coleoides and Isodon, respectively, were subdivided into a number of series. [8] revised the genus in South Africa and based on the inflorescence characters he divided Plectranthus into five subgenera: Nodiflorus Codd, Burnatastrum (Briq) Codd, Coleus (Lour.) Codd, Calceolanthus Codd and Plectranthus based on the inflorescence characters. [9] reviewed the genus Plectranthus and its ethnobotanical used broadly, providing a complete understanding of the global ethno-botany of Plectranthus. Their review touches on the horticultural uses of the genus. In Saudi Arabia, Plectranthus species are used of economic and traditional medicine and have potential for development towards their use in the primary health care system. In Saudi Arabia, Plectranthus barbatus Andr. is the most important species of the genus, and is used as a remedy for stomach, intestine, liver disorders, heart problems, respiratory diseases and it is also resistant to insect attack [10]. Also, P. tenuiflorus (Vatke) Agnew is cultivated as ornamental. The leaf extract of $P$. tenuiflorus is also used to treat ear infections, and the leaves of P. asirensis Wood J. R. I. and P. cylindraceus Benth. are used as antiseptic and deodorant dressing for wounds [11] [12]. Some species of Plectranthus are problematic to identify because of a lack of clear cut morphological criteria to differentiate not only among species within the genus but also among the closely related genera. This has resulted in many taxonomic difficulties in the naming of species with the result that species have often been placed in some closely related genera such as Coleus Lour. [3]. In the Flora of Saudi Arabia, [13] reported Plectranthus by seven species: P. arabicus Bruce E. A., P. cylindraceus, P. tenuiflorus, P. comosus Sims, P. barbatus, P. pseudomarrubioides Willemse R.H. and $P$. asirensis, but [14] accepted only 6 species viz. P. arabicus, $P$. cylindraceus, $P$. tenuiflorus, $P$. lanuginosus (Benth.) Agnew, P. barbatus, and P. asirensis.

Pollen morphology provide a number of characteristics that are potentially useful for species identification, phylogenetic implication, and character-state evolution [15]-[22]. However, there are no works dealing with seed and pollen morphology of Plectranthus. Moreover, trichomes are broadly dispersed over the aerial reproductive and vegetative parts of the members of Lamiaceae and are generally distinguished as glandular and non-glandular trichomes. [17] found that trichome micromorphology was useful for systematics and reconstructing the phylogeny of Lamiaceae. In some genera of Lamiaceae, the trichome morphology is helpful in 
infrageneric classification [23] [24]. Unfortunately, there is not much information on trichome morphology in Plectranthus. Only a few studies have reported on the structure and meaning of the trichomes occurring in Plectranthus and include the species Plectranthus madagascariensis Benth. [25], Plectranthus ornatus Codd [26], Plectranthus neochilus schltr. [27], P. laxiflorus Benth. [28] and P. tenuiflorus [29]. Therefore, this study aims to investigate the morphology and ultrastructure characters of pollen grains and trichomes in order to evaluate their systematic value of these characters in specific and intraspecific separation of the Saudi Arabian Plectranthus species.

\section{Materials and Methods}

\subsection{Plant Material}

Plants were collected during the flowering stages from different places in Saudi Arabia (Appendix 1). The identification was simplified according to [13] [14], and the voucher specimens are deposited at the Herbaria of King Saud University, Kew and Edinburgh (KSU, K and E).

\subsection{Pollen Grain and Seed Characters}

Pollen samples of each studied species were composed from herbarium specimens. All investigations were carried out on acetolysed pollen grains according to [30]. For light microscopy (LM), the pollen grains were observed by an Olympus type BH-2. Photomicrographs were taken with an Olympus photomicroscope. The measurements are based on 20 readings from each slide. The polar axis (P), equatorial diameter (E) and P/E ratio were calculated. For scanning electron microscopy (SEM), acetolysed pollen grains were dehydrated in ethanol sequences and mounted on a metallic stub in few drops of ethanol. The specimens were coated with gold in Apolaron E1100 ion sputtering Device, then viewed at 25 - 30 KV in a JOEL JSM 5300 scanning electron microscope of the Central Laboratory Faculty of Science, Sohag University, Egypt. The terminology and main morphological ideas are based on [31]-[33].

Only mature seeds were taken for investigation. The dried seeds were examined by light microscope (Olympus type BH-2), and 10 - 15 seeds for each taxon were chosen to cover the range of variation. The terminology used here follows authors such as [15] [16] [34].

\subsection{Trichome Morphology}

For trichomes morphology, dried specimens were used. Small portions of leaves or stems were taken and mounted on a stub using double adhesive tape. The specimens were processed as described above. The terminology used follows [25] [26] with some modification.

\subsection{Morphological Characters Observations}

Table 3 shows the characters and character states scored for plant, pollen, trichome and seed morphology, averaged for each OTU. In total 31 characters were taken into consideration, comprising 5 quantitative and 26 qualitative characters. Fifteen of the qualitative characters were scored as binary and the remaining were scored as multi-state characters.

\subsection{Data Analysis}

One type of analyses was performed with NTSYS-pc 2.02k software (Applied Biostatistics Inc., Setauket, New York, USA). I performed a cluster analysis using average taxonomic distance and UPGMA clustering (procedures SIMINT, SAHN, and TREE). To decrease the effects of different scales of measurement for different characters, the values for each character were standardized with procedure STAND, according to the formula: yI, STD = (yi - AVGyi)/STDyi), Where the default value in NTSYS-pc (STAND) for yi = the value to be standardized, AVGyi = the average of all values for the character, and STDyi = the standard deviation. The cophenetic relationship coefficient between the distance matrix and the tree matrix was calculated to examine the goodness of fit of the cluster analysis to the distance matrix (procedures COPH and MXCOMP) [35]. 


\section{Results}

\subsection{Seed Characters}

The seed morphological characters of the studied taxa of the genus Plectranthus as shown by light microscopy are presented in (Table 1).

\subsubsection{Seed Shape}

The seed shape varies from ovoid in P. asirensis, $P$. barbatus and $P$. hijazensis Abdel Khalik, to sub-spherical in the $P$. arabicus, $P$. cylindraceus, $P$. pseudomarrubioides and $P$. tenuiflorus.

\subsubsection{Seed Size}

Seed measurements vary significantly among the examined taxa. The largest seeds were recorded in $P$. asirensis, $P$. barbatus and $P$. hijazensis with ca $1.1-1.5 \times 0.7-1.2 \mathrm{~mm}$ and the smallest ones in $P$. arabicus, $P$. cylindraceus and $P$. pseudomarrubioides measuring $0.6-0.8 \times 0.5-0.6 \mathrm{~mm}$, but in $P$. tenuiflorus has slightly larger seeds, measuring $0.8-1 \times 0.7-0.9 \mathrm{~mm}$.

Table 1. Seed, pollen and trichome characters of the investigated taxa of Plectranthus in Saudi Arabia.

\begin{tabular}{|c|c|c|c|c|c|c|c|}
\hline Characters & P. arabicus & P. asirensis & P. barbatus & $\begin{array}{c}P . \\
\text { cylindraceus }\end{array}$ & P. hijazensis & $\begin{array}{c}P . \\
\text { pseudomarrubioides }\end{array}$ & P. tenuiflorus \\
\hline \multicolumn{8}{|c|}{ Seed morphology } \\
\hline $\begin{array}{l}\text { 1. Seed shape } \\
(\mathrm{mm})\end{array}$ & Sub spherical & Ovoid & Ovoid & Sub spherical & Ovoid & Sub spherical & Sub spherical \\
\hline 2. Seed size & $\begin{array}{c}0.7-0.8 \times 0.6- \\
0.7\end{array}$ & $\begin{array}{c}1.3-1.5 \times 1.1- \\
1.2\end{array}$ & $\begin{array}{c}1.2-1.5 \times 0.8-( \\
1\end{array}$ & $\begin{array}{c}0.7-0.8 \times 0.6- \\
0.7\end{array}$ & $1.1-1.5 \times 0.7-1$ & $0.6-0.7 \times 0.5-0.6$ & $\begin{array}{c}0.8-1 \times 0.7- \\
0.9\end{array}$ \\
\hline 3. Seed color & Reddish-brown & Reddish- brown & Black & Yellow- brown & Reddish- brown & Yellow-brown & Reddish-brown \\
\hline \multicolumn{8}{|c|}{ Pollen morphology } \\
\hline $\begin{array}{l}\text { 4. Polar axis } \\
\qquad(P \mu \mathrm{m})\end{array}$ & $(20-26) \quad 23$ & $(22-30) \quad 26$ & $(26-36) \quad 31$ & $(20-26) \quad 23$ & $(21-25) \quad 23$ & $(16-24) \quad 20$ & $(37$ - 44) 41 \\
\hline $\begin{array}{l}\text { 5. Equatorial } \\
\text { diameter } \\
(\mathrm{E} \mu \mathrm{m})\end{array}$ & $(15-21) \quad 18$ & $(20-25) \quad 22$ & $(20-28) \quad 24$ & $(15-21) \quad 18$ & $(13-16) \quad 15$ & $(14-18) \quad 16$ & (26 - 32) 29 \\
\hline 6. P/E & 1.28 & 1.18 & 1.29 & 1.28 & 1.5 & 1.25 & 1.41 \\
\hline 7. Pollen shape & Subprolate & Subprolate & Subprolate & Subprolate & Prolate & Subprolate & Prolate \\
\hline 8. pollen type & $\begin{array}{c}\text { Hexa- } \\
\text { Zonocolpate }\end{array}$ & $\begin{array}{c}\text { Hexa- } \\
\text { Zonocolpate }\end{array}$ & $\begin{array}{c}\text { Hexa- } \\
\text { Zonocolpate }\end{array}$ & $\begin{array}{c}\text { Hexa- } \\
\text { Zonocolpate }\end{array}$ & $\begin{array}{c}\text { Hexa- } \\
\text { Zonocolpate }\end{array}$ & $\begin{array}{c}\text { Hexa- } \\
\text { Zonocolpate }\end{array}$ & $\begin{array}{c}\text { Hexa- } \\
\text { Zonocolpate }\end{array}$ \\
\hline $\begin{array}{l}\text { 9. Exine } \\
\text { sculpture }\end{array}$ & Bi-reticulate & Bi-reticulate & $\begin{array}{l}\text { Primary lumina } \\
\text { is reticulate and } \\
\text { secondary is } \\
\text { granulate- } \\
\text { perforate }\end{array}$ & Bi-reticulate & $\begin{array}{l}\text { Primary lumina is } \\
\text { reticulate and } \\
\text { secondary } \\
\text { is microreticulate }\end{array}$ & $\begin{array}{l}\text { Primary lumina is } \\
\text { reticulate and } \\
\text { secondary is } \\
\text { microreticulate }\end{array}$ & $\begin{array}{l}\text { Primary } \\
\text { lumina is } \\
\text { reticulate and } \\
\text { secondary is } \\
\text { microreticulate }\end{array}$ \\
\hline \multicolumn{8}{|c|}{ Trichomes morphology } \\
\hline $\begin{array}{l}\text { 10. Unbranched } \\
\text { multicellularhairs }\end{array}$ & + & + & + & + & + & + & + \\
\hline $\begin{array}{l}\text { 11. Bi-cellular } \\
\text { hairs }\end{array}$ & + & - & - & + & - & - & - \\
\hline $\begin{array}{l}\text { 12. Branched } \\
\text { multicellular hairs }\end{array}$ & + & - & - & - & - & - & - \\
\hline $\begin{array}{l}\text { 13. Multicellular } \\
\text { glandular hairs }\end{array}$ & + & - & - & - & - & - & - \\
\hline $\begin{array}{l}\text { 14. Long-stalked } \\
\text { capitate hairs }\end{array}$ & - & - & - & - & + & - & - \\
\hline 15. Peltate hairs & - & - & - & + & & + & - \\
\hline
\end{tabular}




\subsubsection{Seed Color}

The colors of the seeds are of low diagnostic and systematic value among species. The colors vary from reddish-brown in P. arabicus, $P$. asirensis P. hijazensis and P. tenuiflorus, yellowish-brown in $P$. cylindraceus and $P$. pseudomarrubioides, to black in $P$. barbatus.

\subsection{Pollen Grain Characters}

The main features of the investigated pollen grains are summarized in (Table 1). Selected LM and SEM micrographs of pollen grains studied are presented in (Figures 1-3).
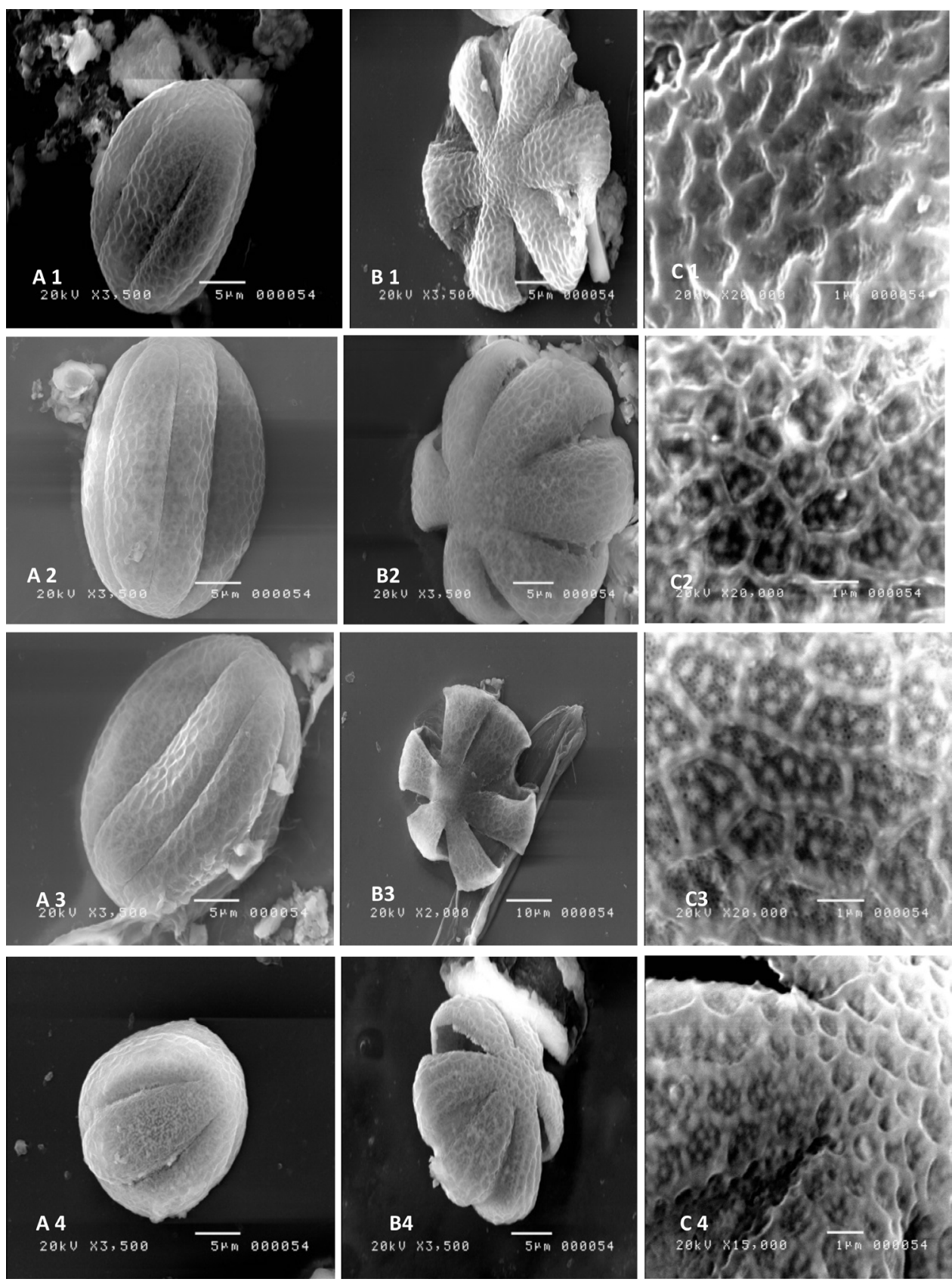

Figure 1. SEM photographs of pollen grains. A: equatorial view; B: polar view; C: enlargement part of pollen grain exine. (A1, B1, C1) P. arabicus, (A2, B2, C2) P. asirensis, (A3, B3, C3) P. barbatus, (A4, B4, C4) $P$. cylindraceus. 


\subsubsection{Pollen Size}

The size of pollen grains varies considerably among the examined taxa (Figure 1, Figure 2), the largest pollen grains in $P$. tenuiflorus have a polar axis of $41 \mu \mathrm{m}$ and an equatorial diameter of $29 \mu \mathrm{m}$ (Figure 2(A7), Figure $3(\mathrm{~B} 7))$ and the smallest grains have an average $P \times E$ value ranging from $20 \times 16 \mu \mathrm{m}$ in $P$. pseudomarrubioides (Figure 2(A6), Figure 2(B6)), while the other species have slightly larger grains of $23-31 \times 18-24 \mu \mathrm{m}$ (see Table 1).

\subsubsection{Pollen Shape}

The ratio between the mean polar axis (P) and the mean equatorial diameter (E) can be used to assign the pollen grains to shape classes.

In the examined species, there is no wide variation in pollen shape. Pollen grains are commonly sub-prolate or prolate. It is prolate in P. tenuiflorus (Figure 2(A7), Figure 2(B7)) and subprolate in the rest of the taxa (Figures 1-3).

\subsubsection{Pollen Apertures}

Apertures are simple. All species investigated are zonocolpate. The colpi are narrow to slit-like after acetolysis, they are usually widest at the equatorial view and gradually narrow towards the poles. The number of colpi is hexacolpate.

\subsubsection{Exine Sculpture}

The exine ornamentation has a complex structure. Generally, the sexine is thicker than nexine. The tectum of the pollen grains in almost all species examined is double-reticulate. The lumina of the main reticulum are in filled by a substratum that is either perforate or reticulate. The main reticulum is referred to as the primary reticulum
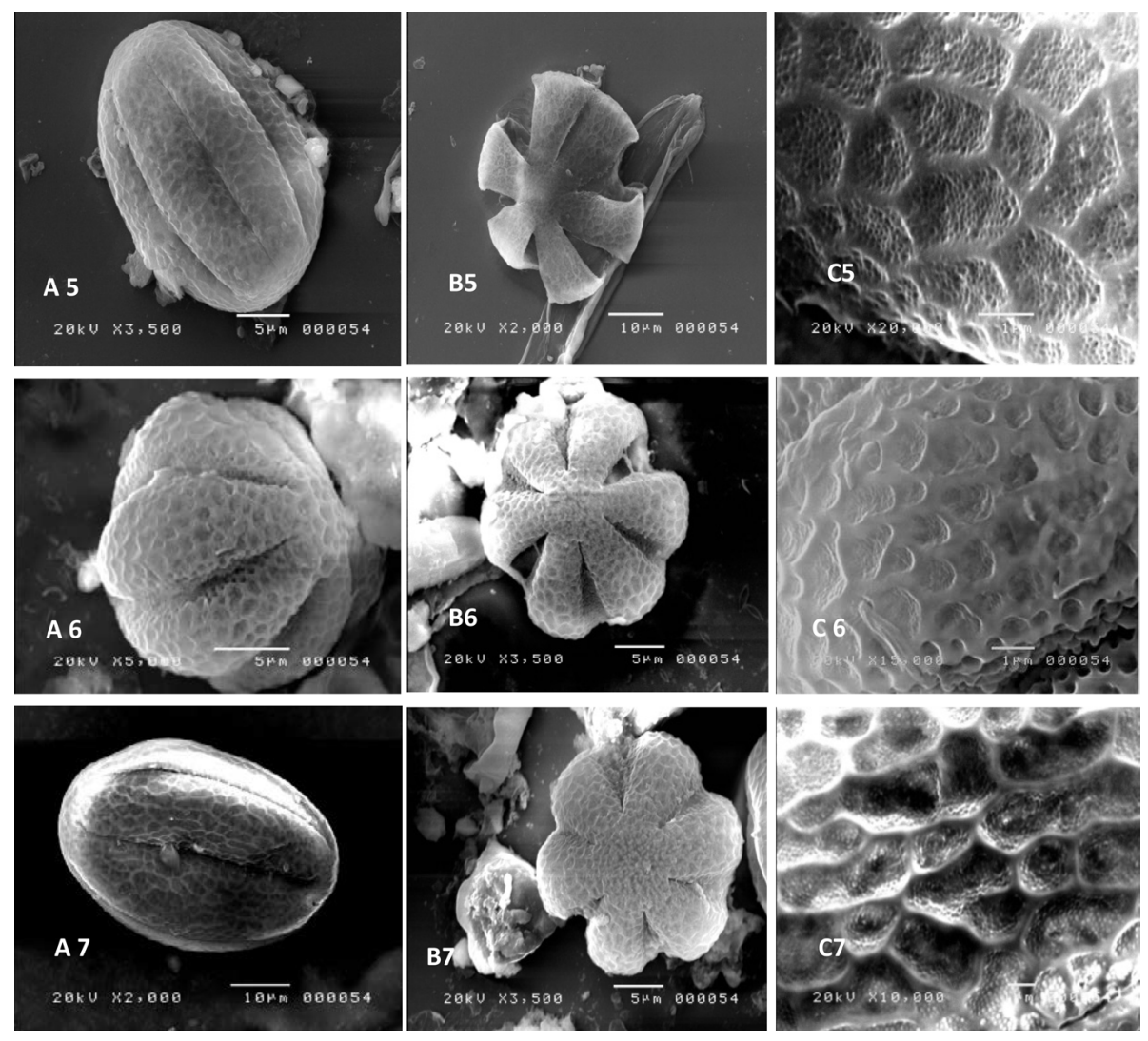

Figure 2. SEM photographs of pollen grains. A: equatorial view; B: polar view; C: enlargement part of pollen grain exine. (A5, B5, C5) P. hijazensis, (A6, B6, C6) P. pseudomarrubioides, (A7, B7, C7) P. tenuiflorus. 


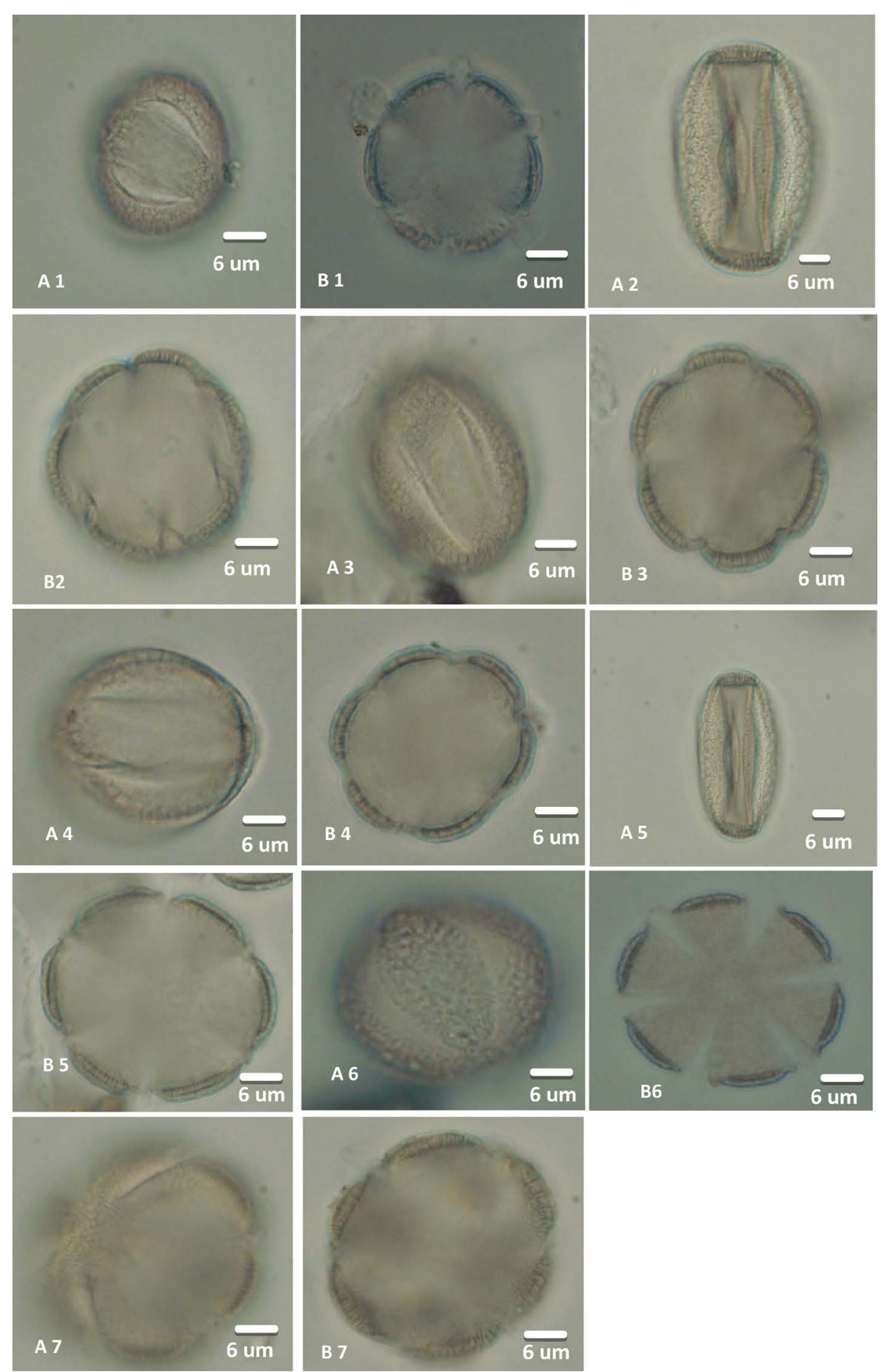

Figure 3. Light microscope photographs of pollen grains. A: equatorial view; B: polar view. (A1, B1) P. arabicus, (A2, B2) P. asirensis, (A3, B3) P. barbatus, (A4, B4) P. cylindraceus, (A5, B5) P. hijazensis, (A6, B6) P. pseudomarrubioides, (A7, B7) P. tenuiflorus.

and the substratum as the secondary reticulum [36]. Concerning the sculpturing of the exine three types can be distinguished:

Type (A): Bi-reticulate (double-reticulate). The primary lumina and the secondary one (substratum) are reticulate in P. arabicus, P. asirensis and P. cylindraceus (Figure 1(C1), Figure 1(C2), Figure 1(C4)). 
Type (B): Granulate-perforate. The primary lumina are reticulate and the secondary one is granulate-perforate in P. barbatus (Figure 1(C3)).

Type (C): Micro-reticulate. The primary lumina is reticulate and the secondary one is micro-reticulate in $P$. hijazensis, P. pseudomarrubioides and P. tenuiflorus (Figure 2(C5)-(C7)).

\subsection{Basic Types of Trichomes}

Observations with Light and Scanning Electron Microscope (LM and SEM) revealed that non-glandular and glandular trichomes on the plant surfaces (Figure 4).

\subsubsection{Non-Glandular Trichomes}

The eglandular trichomes are single, uniseriate, multicellular, pointed, erect or leaning towards the leaf apex. It
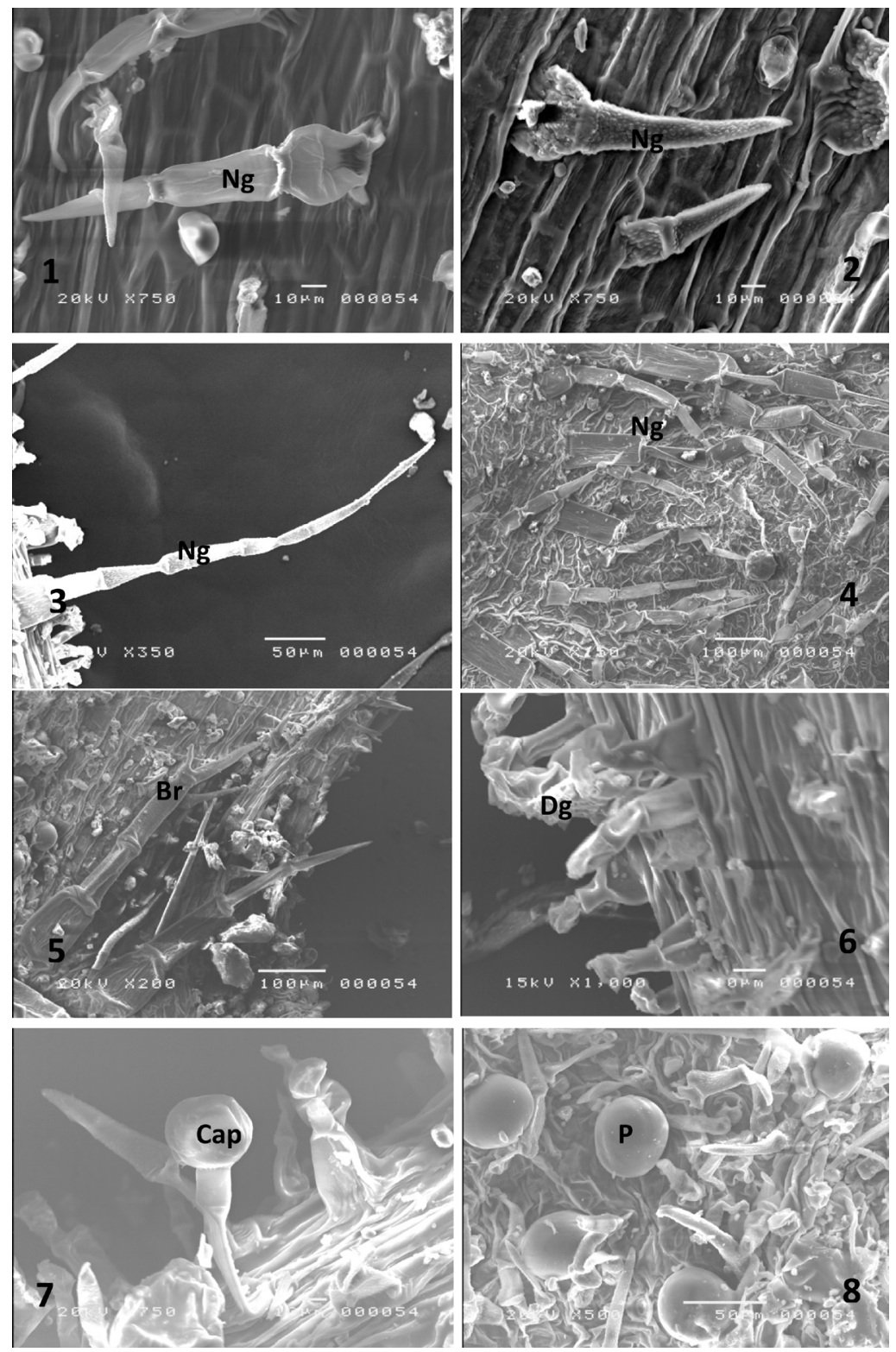

Figure 4. SEM micrographs showing different types of hairs in the genus Plectranthus. (1)-(4) Non-glandular, unbranched multicellularhairs (Ng), (5) Branched multicellular hairs (Br), (6) Digitiform hairs (Dg), (7) Long-stalked Capitate hairs (Cap), (8) Peltate hairs (P). 
consists of two to eight cells. Each non-glandular trichome appears to be supported by a basal cellular pedestal cells. SEM observation revealed the presence of two types of non-glandular trichomes-branched with two fids in $P$. arabicus (Figure 4(5)) and unbranched trichomes which is consisted of 2 - 8 cells in all the species of Plectranthus (Figure 4(1-4)).

\subsubsection{Glandular Trichomes}

The glandular trichomes are of three main types:

\section{1) Peltate trichomes}

This type consists of a basal epidermal cell, a very short stalk cell and a large round head in P. cylindraceus and P. pseudomarrubioides (Figure 4(8)).

\section{2) Capitate trichomes}

This type with long stalked possesses one basal cell, along two to three celled stalk variable length and a unicellular bulb-shaped head in P. hijazensis (Figure 4(7)).

\section{3) Digitiform trichomes}

These consist of two to three cells, in line of similar diameter and approximately equal length. There is no clear distinction between head and stalk cells. Therefore, these glandular trichomes are made up of one basal cell, one or two stalk cells and one apical secretory (head-like) cell in P. tenuiflorus (Figure 4(6)).

\subsection{Cluster Analysis}

The results of the cluster analyses are presented in (Figure 5, Table 2). In the UPGMA dendrogram, 4 major branches and clusters (A-D) with approximately 97\% similarity are distinguished: 1) branch A includes only Plectranthus arabicus; 2) branch B contains only P. barbatus; 3) group C comprises $P$. cylindraceus and $P$. pseudomarrubioides; and 4) group D includes group of $P$. asirensis, $P$. hijazensis and branch of $P$. tenuiflorus. The subgenera and sections show intra variability among themselves. In general, UPGMA indicates that our study follows the currently applied subgenera sectional classification of Plectranthus by [3] [8].

Key to Plectranthus L. species from Saudi Arabia, based on morphological characters

1a. Plant annual, up to $16 \mathrm{~cm}$ long; leaves sessile. P. arabicus

1b. Plant perennial or sub shrub, up to $150 \mathrm{~cm}$ long; leaves petiolated..................................

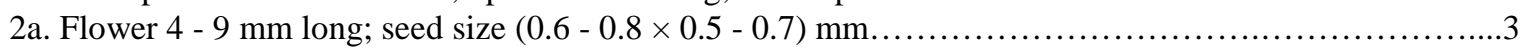

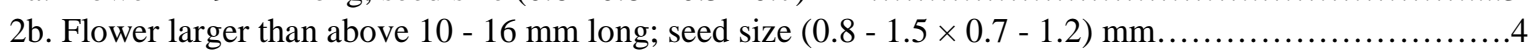

3a. Flower $\leq 4 \mathrm{~mm}$ long; pollen exine sculpture is bi-reticulate............................. cylindraceus

3b. Flower 4 - $10 \mathrm{~mm}$ long; pollen exine sculpture with primary lumina is reticulate and secondary one is microreticulate. .P. pseudomarrubioides

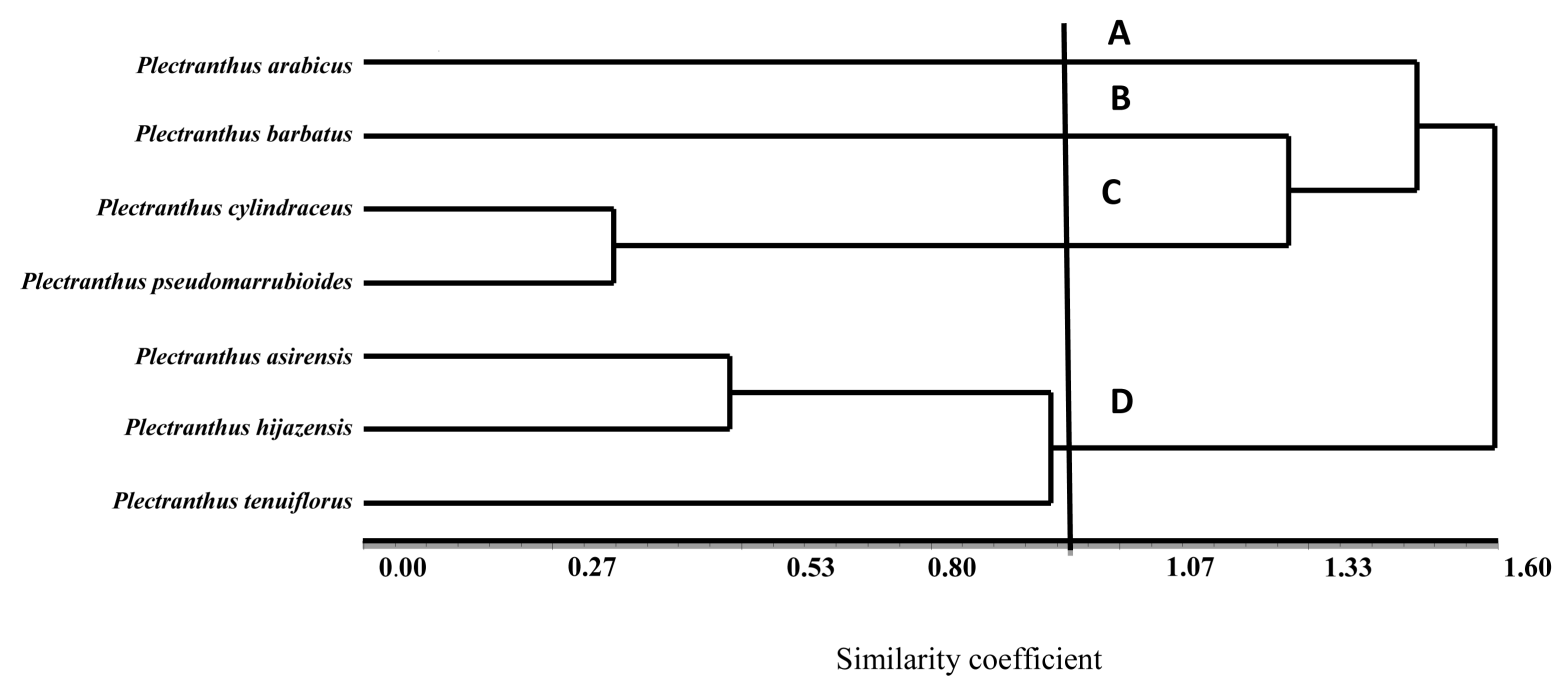

Figure 5. Dendrogram illustrating the relationships of the investigated species of Plectranthus based on morphological characters. 
Table 2. Taxa arranged in alphabetical order according to [13] [14]. The table compares traditional Bentham [4]-[7] and more recent [8] classifications.

\begin{tabular}{|c|c|c|c|c|c|c|}
\hline No & Taxon & $\begin{array}{l}\text { Bentham } \\
\text { (1832-1836) }\end{array}$ & $\begin{array}{l}\text { Benth. \& Hook. } \\
\quad(1876)\end{array}$ & Briquit (1897) & Codd (1975) & $\begin{array}{l}\text { Present } \\
\text { study }\end{array}$ \\
\hline 1 & Plectranthus arabicus E. A. Bruce & Section: Isodon & Section: Isodon & Subgenus: Isodon & - & Group A \\
\hline 2 & Plectranthus asirensis J. R. I. Wood & - & - & - & - & Group D \\
\hline 3 & Plectranthus barbatus Andrews & $\begin{array}{l}\text { Section: Calceolus } \\
\text { (Coleus) }\end{array}$ & Section: Germanea & Subgenus: Germanea & $\begin{array}{l}\text { Subgen. } \\
\text { Calceolanthus }\end{array}$ & Group B \\
\hline 4 & $\begin{array}{l}\text { Plectranthus cylindraceus Hochst. } \\
\text { ex Benth }\end{array}$ & Section: Germanea & Section: Germanea & Subgenus: Germanea & $\begin{array}{l}\text { Subgen. } \\
\text { Burnatastrum }\end{array}$ & Group C \\
\hline 5 & $\begin{array}{c}\text { Plectranthus hijazensis Abdel } \\
\text { Khalik, K }\end{array}$ & - & - & - & - & Group D \\
\hline 6 & $\begin{array}{c}\text { Plectranthus Pseudo marrubioides } \\
\text { R.H. Willemse }\end{array}$ & Section: Germanea & Section: Germanea & Subgenus: Germanea & $\begin{array}{l}\text { Subgen. } \\
\text { Burnatastrum }\end{array}$ & Group C \\
\hline 7 & $\begin{array}{c}\text { Plectranthus tenuiflorus (Vatke) } \\
\text { Agnew }\end{array}$ & $\begin{array}{l}\text { Section: Aromaria } \\
\text { (Coleus) }\end{array}$ & Section: Germanea & Subgenus: Germanea & Subgen. Coleus & Group D \\
\hline
\end{tabular}

4a. Plant succulent; flower with long-pedicels up to $11 \mathrm{~mm}$.... P. tenuiflorus

4b. Plant not succulent; flower with short-pedicels up to $7 \mathrm{~mm}$ ..5

5a. Leaves lanceolate; fruiting pedicels appressed to inflorescence axis; seed black; pollen exine sculpture with primary lumina reticulate and secondary one granulate-perforate. .P. barbatus

5b. Leaves ovate to obovate; fruiting pedicels spreading-erect; seed reddish-brown; pollen exine sculpture with primary lumina reticulate and secondary one either reticulate or microreticulate.....

6a. Inflorescence axis branched, covered with long capitate hairs; pollen grain prolate............P. hijazensis

6b. Inflorescence axis un-branched, covered with long white non-glandular hairs; pollen grain subprolate. P. asirensis

\section{Discussion}

Many authors have tried to provide an accepted system to split the genus Plectranthus into subgenera, sections and series [3]-[8], see Table 2). These studies were based on 1 or 2 characters from these morphological characters such as calyx forms, flower, and inflorescence structure. In the present study a large number of morphological, palynological, seed and trichomes characters were used. In general, the results show that different patterns of the studied characters are helpful in distinguishing various species (Table 3); they do not confirm the subgenera and sectional classification of the genus Plectranthus proposed by Bentham's classifications [4]-[7] but confirm somewhat the subgenera and sectional classification of Plectranthus by [3] [8].

\section{In branch A (P. arabicus)}

Within branch A, [6] treated P. arabicus and P. asirensis as a separate section Isodon. [7] treated these species as subgenus Isodon. Our results do not support the placement of $P$. arabicus with $P$. asirensis in the subgenus (section) Isodon. This is due to the placement of $P$. arabicus within a separate branch with high genetic similarities and distinguishing from the rest of the species by having annual life form; plant length (15 cm); watery- succulent; sessile leaves; Branched and glandular multicellular hairs.

[37] investigated anatomical characters of the stem and leaf in Plectranthus and distinguished P. arabicus from the rest of the species by having terete stem, narrow cortex with only parenchyma, 6 bundles, and covered with bi-multicellular and branched non glandular hairs. Generally, these results disagree with those of [6] [7] regarding placement of $P$. arabicus and $P$. asirensis in an enlarged concept of subgenus Isodon section Isodon and agree with [37] to suggest that $P$. arabicus should be treated as separate subgenus.

Subgenus Calceolanthus Codd (P. barbatus) (branch B)

Within branch B, P. barbatus corresponds to previously recognized position within subgenus Germanea section Germanea [6] [7]. However, [8] reviewed the genus and he put this species within subgenus Calceolanthus. Furthermore, [3] presented a phylogenetic analysis of basils and allies using the DNA sequence of the chloroplast trnL, trnL-trnF inter gene spacer and rps 16. They indicated that Plectranthus is paraphyletic, and within 
Table 3. Characters and character states used in morphometric analysis of the Plectranthus.

\begin{tabular}{|c|c|c|c|}
\hline $\mathbf{N}$ & Character & Character state & Code \\
\hline 1 & Life cycle & $\begin{array}{c}\text { Annual } \\
\text { Perennial or sub shrub }\end{array}$ & $\begin{array}{l}1 \\
2\end{array}$ \\
\hline 2 & Plant nature & $\begin{array}{l}\text { Watery-succulent } \\
\text { Not succulent }\end{array}$ & $\begin{array}{l}1 \\
2\end{array}$ \\
\hline 3 & \multicolumn{3}{|c|}{ Plant length (mean length in cm) } \\
\hline 4 & Plant growth & $\begin{array}{l}\text { Decumbent to ascending } \\
\text { Erect }\end{array}$ & $\begin{array}{l}1 \\
2\end{array}$ \\
\hline 5 & Plant surface & $\begin{array}{l}\text { Glabrous to sparsely hairs } \\
\text { Densely hairs }\end{array}$ & $\begin{array}{l}1 \\
2\end{array}$ \\
\hline 6 & Stem nature & $\begin{array}{c}\text { Herbaceous } \\
\text { Woody at the base } \\
\text { Woody }\end{array}$ & $\begin{array}{l}1 \\
2 \\
3\end{array}$ \\
\hline 7 & Stem outline shape & $\begin{array}{c}\text { Terete } \\
\text { Quadrangular } \\
\text { Terete to quadrangular }\end{array}$ & $\begin{array}{l}1 \\
2 \\
3\end{array}$ \\
\hline \multicolumn{4}{|c|}{ Trichome characters } \\
\hline 8 & Branched multicellular hairs & $\begin{array}{l}\text { Present } \\
\text { Absent }\end{array}$ & $\begin{array}{l}1 \\
2\end{array}$ \\
\hline 9 & Digitiformhairs & $\begin{array}{l}\text { Present } \\
\text { Absent }\end{array}$ & $\begin{array}{l}1 \\
2\end{array}$ \\
\hline 10 & Long-stalked capitate hairs & $\begin{array}{l}\text { Present } \\
\text { Absent }\end{array}$ & $\begin{array}{l}1 \\
2\end{array}$ \\
\hline 11 & Peltate hairs & $\begin{array}{l}\text { Present } \\
\text { Absent }\end{array}$ & $\begin{array}{l}1 \\
2\end{array}$ \\
\hline \multicolumn{4}{|c|}{ Leaf characters } \\
\hline 12 & Leaf nature & $\begin{array}{l}\text { Succulent } \\
\text { Not succulent }\end{array}$ & $\begin{array}{l}1 \\
2\end{array}$ \\
\hline 13 & & Leaf petiole measurements (mean length in mm) & \\
\hline 14 & Leaf shape & $\begin{array}{l}\text { Ovate } \\
\text { Oblong to lanceolate } \\
\text { Ovate to elliptical }\end{array}$ & $\begin{array}{l}1 \\
2 \\
3\end{array}$ \\
\hline 15 & Leaf apex & $\begin{array}{l}\text { Acute } \\
\text { Obtuse }\end{array}$ & $\begin{array}{l}1 \\
2\end{array}$ \\
\hline 16 & Leaf margin & $\begin{array}{l}\text { Serrate } \\
\text { Dentate } \\
\text { Crenate } \\
\text { Lobed }\end{array}$ & $\begin{array}{l}1 \\
2 \\
3 \\
4\end{array}$ \\
\hline \multicolumn{4}{|c|}{ Inflorescence characters } \\
\hline 17 & Inflorescence branching & $\begin{array}{l}\text { Un branched } \\
\text { Branched at the base } \\
\text { Branched at the axis }\end{array}$ & $\begin{array}{l}1 \\
2 \\
3\end{array}$ \\
\hline 18 & Inflorescence position & $\begin{array}{c}\text { Terminal } \\
\text { Terminal and axillary }\end{array}$ & $\begin{array}{l}1 \\
2\end{array}$ \\
\hline 19 & Inflorescence axis surface & $\begin{array}{l}\text { Densely glandular } \\
\text { Glabrous to non-glandular hairs }\end{array}$ & $\begin{array}{l}1 \\
2\end{array}$ \\
\hline 20 & Bract presence & $\begin{array}{l}\text { Permanent } \\
\text { Deciduous }\end{array}$ & $\begin{array}{l}1 \\
2\end{array}$ \\
\hline
\end{tabular}




\section{Continued}

\begin{tabular}{|c|c|c|c|}
\hline \multicolumn{4}{|c|}{ Flower characters } \\
\hline 21 & & Flower pedicle (mean length in mm) & \\
\hline 22 & & Sepal length (mean length in mm) & \\
\hline 23 & Sepal apex & $\begin{array}{l}\text { Acuminate } \\
\text { Acute } \\
\text { Obtuse }\end{array}$ & $\begin{array}{l}1 \\
2 \\
3\end{array}$ \\
\hline 24 & Sepal surface & $\begin{array}{l}\text { Glabrous to sparsely hairs } \\
\text { Hairy with glandular }\end{array}$ & $\begin{array}{l}1 \\
2\end{array}$ \\
\hline 25 & \multicolumn{3}{|c|}{ Petal length (mean length in mm) } \\
\hline 26 & Petal colour & $\begin{array}{c}\text { White } \\
\text { Purple } \\
\text { blue } \\
\text { Purplish-blue }\end{array}$ & $\begin{array}{l}1 \\
2 \\
3 \\
4\end{array}$ \\
\hline \multicolumn{4}{|c|}{ Pllen grain characters } \\
\hline 27 & Pollen shape & $\begin{array}{c}\text { Subprolate } \mathrm{P} / \mathrm{E}=1.14-1.33 \mu \\
\text { ProlateP/E }=1.33-2 \mu\end{array}$ & $\begin{array}{l}1 \\
2\end{array}$ \\
\hline 28 & Exine sculpture & $\begin{array}{l}\text { Bi-reticulate } \\
\text { The primary lumina reticulate and secondary is } \\
\text { micro-reticulate } \\
\text { The primary lumina reticulate and secondary is } \\
\text { granulate-perforate }\end{array}$ & $\begin{array}{l}1 \\
2 \\
3\end{array}$ \\
\hline \multicolumn{4}{|c|}{ Seed characters } \\
\hline 29 & Seed shape & $\begin{array}{c}\text { Ovoid } \\
\text { Sub spherical }\end{array}$ & $\begin{array}{l}1 \\
2\end{array}$ \\
\hline 30 & Seed color & $\begin{array}{c}\text { Yellow-brown } \\
\text { Reddish-brown } \\
\text { Black }\end{array}$ & $\begin{array}{l}1 \\
2 \\
3\end{array}$ \\
\hline 31 & $\begin{array}{l}\text { Seed size in mm } \\
\text { (Length } x \text { width) }\end{array}$ & $\begin{array}{c}0.6-0.8 \times 0.5-0.7 \\
0.8-1 \times 0.7-0.9 \\
1.2-1.5 \times 0.8-1.2\end{array}$ & $\begin{array}{l}1 \\
2 \\
3\end{array}$ \\
\hline
\end{tabular}

Plectranthus, they show that $P$. barbatus clade is well supported (98\% support). Moreover, [38] analyzed the interspecific diversity among four species of Plectranthus: P. grandis (Cramer L. H.) Willemse R. H., P. barbatus, $P$. neochilus Schltr., and $P$. amboinicus (Lour.) Spreng., and the intraspecific diversity of $P$. barbatus in southern Brazil, by means of the RAPD technique. They observed a higher genetic similarity between $P$. grandis and P. barbatus (77\%), and they showed P. barbatus genotypes from different locations in Brazil showed a genetic similarity $96 \%$ - $100 \%$.

The results do not support the situation of $P$. barbatus with other taxa in the subgenus (section) Germanea This is due to the placement of $P$. barbatus within a distinct branch with high genetic similarities and split from the rest of the subgenera on the basis of the species with quadrangular stem, not succulent leaf, terminal inflorescence, black seed, exine sculpture of pollen grain with primary lumina is reticulate and secondary is granulate-perforate. These results disagree with those of [6] [7], but agree with [3] [8] [38].

\section{Subgenus Burnatastrum (Briq) Codd (group C)}

In this group (C), $P$. cylindraceus and $P$. pseudomarrubioides have been recognized with around 0.39 morphological similarities. These species can be clearly defined on the basis of various features: Annual, waterysucculent, glabrous to sparsely hairs, herbaceous, quadrangular stem, covered with peltate hairs, inflorescence branched at the axis, obtuse sepal apex, sub-spherical seed, small seed size $(0.6-0.8 \times 0.5-0.7)$.

Plectranthus cylindraceus and $P$. pseudomarrubioides match to the previously recognized position within subgenus Germanea section Germanea [6] [7]. Furthermore, [8] treated these species as subgenus Calceolan- 
thus. [3] presented a phylogenetic investigation of basils and allies using the DNA sequence of the chloroplast trnL, trnL-trnF, rps 16 and augmented by morphological data. They illustrated that $P$. cylindraceus and $P$. buchananii Baker was separated from the rest of the species of Plectranthus with 98\% support. [9] studied the phylogeny of 62 species of Plectranthus and its ethno-botanical uses extensively. They provided an informal classification that separated the species into two main clades. Clade 1, the Coleus clade of [3], broadly corresponding to the formally recognized genus Coleus, is divided into two subclades, clades $1 \mathrm{a}$ and b. Clade 2 is recognized as the Plectranthus clade. Within subclade $1 \mathrm{~b}$, they proved that P. cylindraceus and P. pseudo- marrubioides are well separated (group 7) from the rest of taxa.

Moreover, [10] surveyed 34 species of Plectranthus for exudate flavonoids to see whether the scattering of these compounds would support a recent classification of the genus based on molecular and morphological characters. They identified two major groups the Coleus and Plectranthus clades. They found that flavanones were restricted to only five species of the Plectranthus, and flavonols were only found in two species of the Coleus clade, $P$. cylindraceus and $P$. pseudomarrubioides. Generally, these data are support and congruent with those of [3] [6]-[10].

\section{Subgenus Coleus (Lour.) Codd (group D)}

Within group D, one major cluster and branch with 0.97 similarities were identified. The first cluster includes the endemic $P$. asirensis and $P$. hijazensis. However, the second branch includes $P$. tenuiflorus treated as section Aromaria Benth. that belongs to the genus Coleus, as subgenus Germanea, and subgenus Coleus that belong to Plecranthus. [9] treated P. tenuiflorus, P. asirensis and other connected within one group (group 8) but in two separated sub-clades (1a and 1b).

Inside the cluster of the endemic $P$. asirensis and $P$. hijazensis have been recognized with 0.45 morphological similarities. These species can be clearly defined on the basis of various structures: sub-shrubs, not succulent, erect, woody stem at the base, terete to quadrangular stem outline, petiolate leaves, serrate leaf margins, bracts deciduous, ovoid seed, seed size $(1.2-1.5 \times 0.8-1.2)$. Moreover, [37] showed that the anatomical characters of the stem and leaf might be useful in distinguishing $P$. asirensis and $P$. hijazensis from the rest of the species by their shared terete to undulate stem, wide cortex with angular collenchyma and parenchyma, numerous bundles.

An another branch of the species represented by $P$. tenuiflorus shares the same densely hairs surface, woody stem, terete to quadrangular stem outline, petiolate leaves, terminal inflorescence, bract deciduous, hairy with glandular sepal surface, reddish-brown seed.

Current observations confirmed the possibility that $P$. asirensis and $P$. hijazensis should be a monophyletic group and there are close relationships between these species and $P$. tenuiflorus subgenus Germanea, and subgenus Coleus and these results are in agreement with the results of [8] [9] [37].

\section{Conclusion}

A taxonomic revision of seven Plectranthus species (Lamiaceae) in Saudi Arabia was conducted by means of numerical analysis based on thirty-one morphological characters, including vegetative parts, seeds, pollen grains, and trichomes. Macro- and micro-morphological characters, including seed and pollen shape, size, coat sculpture, trichome structure, were studied. Two endemic species exist. The data presented here considerably underline the importance of seed, pollen and trichome characters within the genus Plectranthus both on subgeneric and sectional levels. Some species of Plectranthus have similar trichome shapes, pollen grains and seed characters, but are quite different in gross morphology and can easily be recognized as distinct species. The molecular systematic study on Plectranthus [3] [9] including some species distributed in Saudi Arabia, allows an interpretation of the usefulness of pollen, trichome and seed characters in Plectranthus, these can be considered as phylogenetic informative characters. Our results indicate some degree of similarity among the species of subgenus Burnatastrum (Briq) Codd and support the monophyly of the subgenus as suggested by [8] [9]. A remarkable result from this study was identifying $P$. arabicus as a separate group and suggesting that it should be treated as a separate subgenus. Furthermore, the endemic $P$. asirensis and $P$. hijazensis appear to be a homogeneous group and there are close relationships between this group and P. tenuiflorus. A key for the identification of the investigated taxa based on studied characters is provided.

\section{Acknowledgements}

The author would like to thank the Deanship of Scientific Research and the Institute of Scientific Research and 
Revival of Islamic Heritage at Umm Al-Qura University (Project ID: 43405063) for the financial support. Also, I am grateful to the directors and curators of the King Saud University, Kew and Edinburgh Herbaria (KSU, K and E). My great thanks are due to Prof. Dr. van der Maesen, Professor of Plant Taxonomy in Biosystematics group, Plant Science, Wageningen University, the Netherlands for going through the manuscript and making valuable suggestions. Moreover, I am indebted to Prof. Dr. Mohamed Abdel Wahab, Botany Department, Faculty of Science, University of Sohag for his kind help in Light Microscope Photomicrographs.

\section{References}

[1] Codd, L.E. (1985) Lamiaceae. In: Leistner, O.A., Ed., Flora of Southern Africa, Vol. 28, Part 4, Botanical Research Institute Department of Agriculture and Water Supply, Pretoria, 137-172.

[2] Retief, E. (2000) Lamiaceae (Labiatae). In: Leistner, O.A., Ed., Seed Plants of Southern Africa: Strelitzia, Vol. 10, 323-334.

[3] Paton, A.J., Springate, D., Suddee, S., Otieno, D., Grayer, R.J., Harley, M.M., Willis, F., Simmonds, M.S.J., Powel, M.P. and Savolainen, V. (2004) Phylogeny and Evolution of Basils and Allies (Ocimeae, Labiatae) Based on Three Plastid DNA Regions. Molecular Phylogenetics and Evolution, 31, 277-299. http://dx.doi.org/10.1016/j.ympev.2003.08.002

[4] Bentham, G. (1832) Labiatarum, Genera et Species: 1 - 60. James Ridgway and Sons, London.

[5] Bentham, G. (1848) Labiatae. In: de Candolle, A.P., Ed., Prodromus, Vol. 12, Treuttel et Wurtz, Paris, 55.

[6] Bentham, G. and Hooker, J.D. (1867) Genera Plantarum Vol. 2. Reeve, London.

[7] Briquet, J. (1897) Ocimum. In: Engler, A. and Prantl, K., Eds., Die Natürlichen Pflanzenfamilien, W. Engelmann, Leipzig, 369-372.

[8] Codd, L.E. (1975) Plectranthus (Labiatae) and Allied Genera in Southern Africa. Bothalia, 11, 371-442. http://dx.doi.org/10.4102/abc.v11i4.1482

[9] Lukhoba, C.W., Simmonds, M.S.J. and Paton, A.J. (2006) Plectranthus: A Review of Ethno Botanical Uses. Journal of Ethnopharmacology, 103, 1-24. http://dx.doi.org/10.1016/j.jep.2005.09.011

[10] Grayer, R.J., Eckert, M.R., Lever, A., Veitch, N.C., Kite, G.C. and Paton, A.J. (2010) Distribution of Exudate Flavonoids in the Genus Plectranthus. Biochemical Systematics and Ecology, 38, 335-341. http://dx.doi.org/10.1016/j.bse.2010.01.014

[11] Abulfatih, H.A. (1987) Medicinal Plants in South Western Saudi Arabia. Agriculture and Water Supply. Economic Botany, 41, 354-360. http://dx.doi.org/10.1007/BF02859051

[12] Marwah, R.G., Fatope, M.O., Mahrooqi, R.A., Varma, G.B., Abadi, H.A. and Al-Burtamani, S.K.S. (2007) Antioxidant Capacity of Some Edible and Wound Healing Plants in Oman. Food Chemistry, 101, 465-470. http://dx.doi.org/10.1016/j.foodchem.2006.02.001

[13] Collenette S. (1999) Wild Flowers of Saudi Arabia. National Commission for Wildlife Conservation and Development (NCWCD), Riyadh.

[14] Chaudhary, S.A. (2001) Flora of the Kingdom of the Saudi Arabia, Vol. II. Ministry of Agriculture and Water, Riyadh, 342-354.

[15] Barthlott, W. (1981) Epidermal and Seed Surface Characters of Plants: Systematic Applicability and Some Evolutionary Aspects. Nordic Journal of Botany, 1, 345-355. http://dx.doi.org/10.1111/j.1756-1051.1981.tb00704.x

[16] Barthlott, W. (1984) Microstructural Features of Seed Surface. In: Heywood, V.H. and Moore, D.C., Eds., Current Concepts in Plant Taxonomy, Academic Press, Cambridge, 95-105.

[17] Abu-Assab, M.S. and Cantino, P.D. (1987) Phylogenetic Implications of Leaf Anatomy in Subtribe Melittidinae (Labiatae) and Related Taxa. Journal of the Arnold Arboretum, 68, 1-34.

[18] Moazzeni, H., Zarre, S., Al-Shehbaz, I.A. and Mummenhoff, K. (2007) Seed Coat Microsculpturing and Its Systematic Application in Isatis (Brassicaceae) and Allied Genera in Iran. Flora-Morphology, Distribution, Functional Ecology of Plants, 202, 447-454. http://dx.doi.org/10.1016/j.flora.2006.10.004

[19] Abdel Khalik, K.N. (2010) Seed Coat Morphology Its Systematic Significance in Juncus L. (Juncaceae) in Egypt. Journal of Systematics and Evolution, 48, 215-223. http://dx.doi.org/10.1111/j.1759-6831.2010.00075.x

[20] Abdel Khalik, K.N. (2013) Systematic Implications of Seed Coat Diversity in Some Representatives of the Genus Ipomoea (Convolvulaceae). Turkish Journal of Botany, 37, 811-824. http://dx.doi.org/10.3906/bot-1302-56

[21] Abdel Khalik, K. and Hassan, N.S. (2012) Seed Coat Trichome Micromorphology of Egyptian Fagonia (Zygophyllaceae) with Emphasis on Its Systematic Implication. Nordic Journal of Botany, 30, 116-126. 
http://dx.doi.org/10.1111/j.1756-1051.2011.01112.x

[22] Hassan, N.S. and Abdel Khalik, K.N. (2014) The Systematic Significance of the Seed Morphology of the Genus Veronica L. (Plantaginaceae) with Special Reference to the Egyptian Taxa. Journal of Systematics and Evolution, 52, 215230. http://dx.doi.org/10.1111/jse.12054

[23] Marin, P.D., Petkovic, B. and Duletic, S. (1994) Nutlet Sculpturing of Selected Teucrium Species (Lamiaceae): A Character of Taxonomic Significance. Plant Systematics and Evolution, 192, 199-214. http://dx.doi.org/10.1007/BF00986252

[24] Navarro, T. and El Oualidi, J. (2000) Trichome Morphology in Teucrium L. (Labiatae). A Taxonomic Review. Anales del Jardín Botánico de Madrid, 57, 277-297.

[25] Ascensao, L., Figueiredo, A.C., Barroso, J.G., Pedro, L.G., Schripsema, J., Deans, S.G. and Scheffer, J.J.C. (1998) Plectranthus madagascariensis: Morphology of the Glandular Trichomes, Essential Oil Composition, and Its Biological Activity. International Journal of Plant Sciences, 159, 31-38. http://dx.doi.org/10.1086/297518

[26] Ascensão, L., Mota, L. and Castro, M.M. (1999) Glandular Trichomes on the Leaves and Flowers of Plectranthus ornatus: Morphology, Distribution and Histochemistry. Annals of Botany, 84, 437447. http://dx.doi.org/10.1006/anbo.1999.0937

[27] Duarte, M.D.R. and Lopes, J.F. (2007) Stem and Leaf Anatomy of Plectranthus neochilus Schltr., Lamiaceae. Revista Brasileira de Farmacognosia, 17, 549-556. http://dx.doi.org/10.1590/S0102-695X2007000400013

[28] Arvind, B., Naidoo, Y. and Nicholas, A. (2010) The Foliar Trichomes of Plectranthus laxiflorus Benth [Lamiaceae]: An Important Medicinal Plant. New Zealand Journal of Botany, 48, 55-61. http://dx.doi.org/10.1080/0028825X.2010.482958

[29] Waly, N. and El Gayed, S. (2012) Botanical and Biological Studies of Plectranthus tenuiflorus (Vatke) Agnew. (Lamiaceae) Growing in Saudi Arabia. Life Sciences, 2, 52-64.

[30] Moore, P.D., Webb, J.A. and Collinson, M.E. (1991) Pollen Analysis. 2nd Edition, Blackwell, Oxford, 1-216.

[31] Erdtman, G. (1943) An Introduction to Pollen Analysis. Chronica Botanica Company, Waltham, 1-239.

[32] Harley, R.M. and Reynolds, T. (Eds.) (1992) Advances in Labiate Science. Royal Botanic Gardens, Kew, 125-138.

[33] Punt, W., Blachmore, S., Nillsson, S. and Thoams, L.F. (1994) Glossary of Pollen and Spore Terminology. LPP Contributions Ser. 1, Utrecht.

[34] Abdel khalik, K. and Van der Maesen, L.J.G. (2002) Seed Morphology of Some Tribes of Brassicaceae (Implications for Taxonomy and Species Identification for the Flora of Egypt). Blumea, 47, 363-383.

[35] Rohlf, F.J. (1972) An Empirical Comparison of Three Ordination Techniques in Numerical Taxonomy. Systematic Zoology, 21, 271-280. http://dx.doi.org/10.2307/2412165

[36] Luque, T. and Candau, P. (1987) Lamiaceae (Labiatae). In: Valdes, B., Diez. J. and Fernandez, I., Eds., Atlas polinico de Andalucia Occidental. Inst. Desarrol. Reg. 43, Univ de Sevilla, Cadiz, Sevilla Press, 283-291.

[37] Abdel Khalik, K. and Karakish, E. (2016) Comparative Anatomy of Stems and Leaves of Plectranthus L. (Lamiaceae) in Saudi Arabia and Systematic Implications. Microscopy Research and Technique, 79, 583-594.

[38] Bandeira, J.M., Bianchi, V.J., Rubin, S., Peters, J.A. and Braga, E.J.B. (2010) Genetic Similarities among Four Species of the Plectranthus (L’Hér.) Genus. Maringá, 32, 43-48. http://dx.doi.org/10.4025/actascibiolsci.v32i1.880 


\section{Appendix 1}

List of Plectranthus taxa and specimens studied [13] [14].

1. Plectranthus arabicus E. A. Bruce: Saudi Arabia. Jazan: Gabal Fayfa, Abdel Khalik s. n. (UQU); Gabal Fayfa, $100 \mathrm{~km}$ NE of Trajam, on steep SW approach road, S. Collenette 3570 (E, K).

2. Plectranthus asirensis J. R. I. Wood: Saudi Arabia. Abha: Wadi Al-ouse, A.K. Nashar IH 98 (E); Jazan: Jabal Fayfa, Taku Miyazaki 10203 JF H20 (E); Jazan: Gabal Fayfa, Abdel Khalik and Al-Ozekii s.n. (UQU); Abha: Raydah village, city, Taku Miyazaki 10205RV 2445 (E).

3. Plectranthus barbatus Andrews: Saudi Arabia. Jazan: Gabal Fayfa, Abdel Khalik s.n. (UQU); Jazan: Jabal Fayfa, S. Chaudary 385 (E); Taif: near Al Hadda, S. Collenette 2387 (K); Abha: Raydah village, Taku Miyazaki 990906R4 (E).

4. Plectranthus cylindraceus Hochst. ex Benth: Saudi Arabia. Abha: Wadi Al-ouse, Abdel Khalik and Howldars s. n. (UQU); Wadi Al-ouse, Jabal Sawdah, near police station, S. Collenette 6364 (E, K); Al-Baha: Jabal Shada, $25 \mathrm{Km}$ north of Mikhas, S. Collenette 9306 (E, K).

5. Plectranthus pseudomarrubioides R. H. Willemse: Saudi Arabia. Jazan: Gabal Fayfa, Abdel Khalik and Al-Ozekii s.n. (UQU).

6. Plectranthus tenuiflorus (Vatke) Agnew: Saudi Arabia. Jazan: in area of Gabal Fayfa, Abdel Khalik s.n. (UQU); Abha: Wadi Al-ouse, Jabal Sawdah, near police station, Collenette 3119 (K, E).

7. Plectranthus hijazensis K. Abdel Khalik: Saudi Arabia. Al Baha: in area of Saad Medhas, Abdel Khalik and Howldar s.n. (UQU); Agabat Al-Abna, SE Buljurashi, Fayed 13922 (K); Near Taif, 15 Km SW of Al-Hadda, S. Collenette 1554 (K); Near Jabal Ibrahim of Taif, Al Baha road, S. Collenette 3552(K, E).

\section{Submit or recommend next manuscript to SCIRP and we will provide best service for you:}

Accepting pre-submission inquiries through Email, Facebook, LinkedIn, Twitter, etc. A wide selection of journals (inclusive of 9 subjects, more than 200 journals)

Providing 24-hour high-quality service

User-friendly online submission system

Fair and swift peer-review system

Efficient typesetting and proofreading procedure

Display of the result of downloads and visits, as well as the number of cited articles

Maximum dissemination of your research work

Submit your manuscript at: http://papersubmission.scirp.org/ 